Poznań

\title{
Europejska inicjatywa obywatelska - uwagi na temat roli obywateli w procesie integracji europejskiej
}

Partycypacja obywatelska od długiego czasu jest przedmiotem wielu debat nie tylko wśród polityków, ale także na poziomie akademickim. Wynika to zapewne z faktu, iż zaangażowanie obywateli w przestrzeni politycznej (przede wszystkim w wyborach) postrzegane jest jako swego rodzaju panaceum na tzw. deficyt demokratyczny. Ten $\mathrm{z}$ kolei jest zagadnieniem, które używane jest nie tylko w odniesieniu do państw narodowych, a także do ponadnarodowych struktur - w tym do Unii Europejskiej (Chalmers, 2011, s. 2). Powszechne są opinie, iż „współczesna demokracja parlamentarna stoi w obliczu kryzysu, który przejawia się m.in. w wadliwie funkcjonujących najważniejszych instytucjach państwowych, które nie spełniają we właściwy sposób swoich podstawowych funkcji. W konsekwencji takiego stanu obserwuje się spadek społecznego zaufania względem organów władzy. Jedną z najważniejszych oznak kryzysu demokracji jest zmniejszający się systematycznie poziom frekwencji wyborczej w elekcjach państwowych, w referendach, a także w wyborach o charakterze ponadnarodowym" (Musiał-Karg, 2012a, s. 77).

Podkreślając niejako wagę problemu związanego z istnieniem deficytu demokratycznego, zajmowała się nim również i sama Unia Europejska, która jest często krytykowana za brak wystarczającej ilości procedur demokratycznych w kreowaniu polityk unijnych, za brak dostatecznej jawności i przejrzystości procedur decyzyjnych (Hassing, 2011). W odpowiedzi na ten problem na poziomie UE podejmowane są próby przezwyciężenia deficytu poprzez między innymi włączanie przedstawicieli społeczeństwa obywatelskiego w kształtowanie polityk unijnych (Berg, 2008; Głogowski, Hauser, 2013, s. 8). Należy jednak uwzględnić, iż w przypadku Unii Europejskiej poszukiwanie sposobu na zniwelowanie deficytu demokratycznego, czyli próba niejako kreowania własnego modelu demokracji, jest jednocześnie poszukiwaniem odpowiedzi na pytanie o ostateczny kształt polityczny Unii oraz szukaniem sposobu na legitymizowanie samej UE, jej instytucji oraz decyzji podejmowanych na jej forum.

Europejska inicjatywa obywatelska traktowana jest jako jedno z narzędzi, mających na celu wpływ na zmniejszenie deficytu demokratycznego w UE. Jest też instrumentem, który miał być realizacją postulatu zawartego w Traktacie lizbońskim (Mayoral, 2011, s. 10), by zrównać w ramach systemu przedstawicielskiego demokrację bezpośrednią z pośrednią (Sauron, 2011, s. 1).

Przedmiotem niniejszych rozważań jest zagadnienie roli bezpośrednich mechanizmów decydowania politycznego w procesie integracji europejskiej, ze szczególnym uwzględnieniem funkcjonującej od 2012 r. europejskiej inicjatywy obywatelskiej. Mo- 
tywacją do zajęcia się tą problematyką jest fakt, iż państwa członkowskie UE, szczególnie w ostatnich latach, dość często przekazują decyzje związane z funkcjonowaniem Unii Europejskiej obywatelom, aby ci właśnie w drodze narzędzi demokracji bezpośredniej (referendum) - podjęli finalne decyzje lub przynajmniej wyrazili swoje zdanie w wybranych kwestiach unijnych. Celem niniejszego tekstu jest udzielenie odpowiedzi na pytanie o rolę i o perspektywy rozwoju europejskiej inicjatywy obywatelskiej jako instrumentu wpływu obywateli na decyzje ,europejskie” (szans, ograniczeń) w kontekście podejmowania decyzji w UE za pomocą narzędzi demokracji bezpośredniej.

Stawiając pytanie o naturę rozwiązań instytucjonalnych przyjętych w Unii Europejskiej, oczywistą odpowiedzią jest ta, iż fundamentem funkcjonowania systemu politycznego samej Unii - podobnie zresztąjak wszystkich jej państw członkowskich - jest demokracja przedstawicielska. W demokracji reprezentatywnej centralnym mechanizmem sprawowania władzy są wybory, będące sposobem opowiedzenia się głosujących za konkretnym programem politycznym, a także sposobem elekcji osób ubiegających się o stanowiska polityczne.

Demokracja przedstawicielska często uzupełniana jest formami demokracji bezpośredniej, gdzie uprawnieni do głosowania mają możliwość bezpośredniego wpływu na kształt agendy politycznej. Warto zauważyć, iż w większości państw członkowskich UE elementy demokracji reprezentacyjnej łączone są z rozwiązaniami charakterystycznymi dla demokracji bezpośredniej, co często argumentowane jest potrzebą zaangażowania obywateli $\mathrm{w}$ procesy podejmowania decyzji $\mathrm{w}$ istotnych kwestiach państwowych. Dzięki takim rozwiązaniom obywatele mają bowiem możliwość składania propozycji legislacyjnych czy głosowania w referendach. Praktyka wykorzystania instytucji demokracji bezpośredniej w państwach unijnych dowodzi, iż prócz licznych głosowań referendalnych w sprawach państwowych, również kwestie „europejskie” („unijne") stają się coraz bardziej popularnym przedmiotem debaty publicznej, a następnie głosowania. Dowodem na to są zapewne liczne referenda narodowe w sprawach związanych z procesem integracji europejskiej przeprowadzane w państwach członkowskich czy kandydujących do UE. Większość - wydaje się - doświadczeń związanych z zastosowaniem referendów w sprawach „europejskich” jest pozytywnych, jednak część z nich przysporzyło państwom członkowskim i samej Unii wielu problemów - m.in. z ratyfikacją traktatów unijnych.

Unia Europejska ma - można rzec - dość traumatyczne doświadczenia związane z referendami w sprawie niektórych traktatów, nad którymi trzeba było głosować dwukrotnie, bowiem pierwsze referenda w poszczególnych państwach okazały się przegrane przez zwolenników pogłębiania integracji europejskiej. Jako przykłady wymienić tu można duńskie głosowania powszechne z 1992 i 1993 r. w sprawie przyjęcia Traktatu z Maastricht czy irlandzkie ,powtarzane” referenda w sprawie Traktatu z Nicei (z 2001 i 2002 r.) i w sprawie Traktatu z Lizbony (z 2008 i potem z 2009 r.). Zwrócić ponadto należy uwagę na dwa referenda ogólnonarodowe z 2005 r. nad Traktatem ustanawiającym „Konstytucję dla Europy”. Oba głosowania - francuskie z 29 maja oraz holenderskie z 1 czerwca zakończyły się rozstrzygnięciem negatywnym, co też wywołało „kryzys ratyfikacyjny” w Unii Europejskiej. Taki stan rzeczy spowodował, iż państwa, które planowały przeprowadzenie referendum w tej sprawie (za wyjątkiem Luksemburga - referendum 10 lipca), wstrzymały się z głosowaniami powszechnymi (np. 
Wielka Brytania) (Kużelewska, 2011). Ogłoszony w czerwcu 2005 r. , okres refleksji” nad traktatem konstytucyjnym pokazał, że przyjęcie TKE w kształcie przyjętym w 2004 r. będzie praktycznie niemożliwe. Po podpisaniu w grudniu 2007 r. Traktatu z Lizbony, który miał na celu modyfikację dotychczasowych traktatów unijnych m.in. poprzez włączenie do nich części postanowień traktatu konstytucyjnego, tylko jedno państwo - Irlandia - przekazało kwestię ratyfikacji Traktatu w ręce obywateli. Pierwsze głosowanie - przegrane - odbyło się w czerwcu 2008 r., a ponowne - tym razem zakończone zatwierdzeniem przedmiotu referendum - miało miejsce w październiku 2009 r. Każdorazowo, gdy obywatele z jakiegoś państwa UE odrzucali któryś z traktatów mówiło się po tym, że Unia Europejska przeżywa kryzys integracji. Z kolei gdy przeprowadzano po raz kolejny referendum w tej samej sprawie w jednym ze wspomnianych państw, stawiano pytania o to, czy dopuszczalnym jest, by w państwach demokratycznych przeprowadzano dwukrotnie referendum praktycznie w tej samej kwestii. Czasami groźba referendum - jak w przypadku zapowiedzi greckiego referendum w $2011 \mathrm{r}$. w sprawie drugiego pakietu pomocy dla Aten - wywołuje nie tylko zamieszanie na rynkach finansowych oraz dezorientację europejskich przywódców, ale także polityczne konsekwencje w postaci dymisji szefa rządu (premier Jeorjos Papandreu) (Premier Papandreu..., 2011; Grecja: referendum ..., 2011). Wiele kontrowersji budzi również zapowiedź premiera Wielkiej Brytanii - Davida Camerona - który wychodząc naprzeciw frustracjom Brytyjczyków, którzy nie są zadowoleni z obecnego kształtu UE - zaproponował przeprowadzenie referendum w sprawie dalszego członkostwa w Unii.

Kryzys ekonomiczny osłabił poparcie dla działań Unii Europejskiej, której często zarzuca się brak odpowiedzialności demokratycznej, gdyż traktaty w większości państw członkowskich są przyjmowane przez parlamenty narodowe bez bezpośredniego zaangażowania obywateli. Uczestnictwo uprawnionych w głosowaniach powszechnych stanowi jedno z najważniejszych zagadnień związanych z rolą suwerena $\mathrm{w}$ systemie demokratycznym. Zaangażowanie obywateli w procesy podejmowania decyzji politycznych w Unii Europejskiej wg wielu powinno być jednym z najbardziej znaczących elementów legitymizujących działania UE.

\section{Demokracja bezpośrednia a podejmowanie decyzji dotyczących integracji europejskiej}

Wzrost zainteresowania wykorzystaniem instytucji demokracji bezpośredniej w Europie jest wynikiem charakteru przemian politycznych, jakie miały i mają nadal miejsce w państwach starego kontynentu. Większe niż wcześniej zainteresowanie bezpośrednimi formami demokratycznymi odnotować można zarówno w państwach zachodnioeuropejskich, jak i w Europie Środkowej i Wschodniej. Płaszczyzną wspólną obu grup jest proces integracji europejskiej, który to w różnych kontekstach był i jest przedmiotem wielu referendów przeprowadzonych w państwach członkowskich UE, jak i tych które nie należą do Unii, ale utrzymują z nią różnego rodzaju relacje (Kużelewska, 2006; Musiał-Karg, 2008).

Warto w tym miejscu zauważyć, iż obecnie w związku z kryzysem finansowym, który dotknął nie tylko Europę jako kontynent, ale przede wszystkim Unię Europejską 
(a precyzyjniej tzw. strefę euro) istnieje pewne zagrożenie związane z wykorzystaniem referendum w celu rozstrzygania problemów natury europejskiej. Mowa tu o sytuacjach, kiedy rządzący w poszczególnych państwach członkowskich UE, chcąc zdjąć z siebie odpowiedzialność podejmowania trudnych decyzji np. finansowych, przedkładaliby bardzo skomplikowane kwestie do rozstrzygnięcia wyborcom (przykład Grecji) (Grecja: będzie..., 2011).

Analizując doświadczenia związane z wykorzystaniem demokracji bezpośredniej w różnych sprawach europejskich zauważyć należy, iż od pierwszego głosowania powszechnego we Francji w 1972 r. do końca maja 2014 r. przeprowadzano łącznie 54 referenda narodowe w sprawach związanych z integracją europejską. Referenda przeprowadzane były zarówno w państwach członkowskich, jak i w państwach kandydujących, czy też w państwach, które do struktur unijnych nie należą jednak w różnym stopniu i na różnych płaszczyznach z nią kooperują.

Państwa członkowskie UE, a także kilka państw tzw. trzecich (niebędących w strukturach UE) wykorzystywały referenda wielokrotnie przy kształtowaniu struktur Unii, ustalaniu warunków i kierunków polityki integracyjnej na kontynencie europejskim.

Nadmienić należy, iż w europejskich referendach dominują dwa rodzaje problemów przedkładanych do rozstrzygnięcia wyborcom: po pierwsze - referenda akcesyjne, a po drugie referenda w sprawie traktatów. Obywatele państw europejskich coraz częściej mają okazję wyrażać swoje zdanie w tych sprawach - mimo iż (szczególnie kwestie traktatów) są bardzo skomplikowane i złożone (Musiał-Karg, 2012a, s. 212-215).

Dotychczasowe doświadczenia związane z wykorzystaniem instytucji referendum w kwestiach integracji europejskiej pozwalają stwierdzić, iż liczba referendów państwowych przeprowadzonych $\mathrm{w}$ sprawach związanych w różnym stopniu z integracją europejską stanowi niewątpliwy dowód na istotną rolę, jaka przypisywana jest głosowaniom powszechnym właśnie w rozstrzyganiu kwestii europejskich. Referendum narodowe niewątpliwie stało się popularnym narzędziem demokracji bezpośredniej, za pośrednictwem którego wyborcy wyrażają swoją opinię co do przedkładanych im spraw natury ponadnarodowej. Europejczycy są pionierami jeżeli chodzi o liczbę państw przeprowadzających referenda oraz liczbę głosowań nad jedną szeroko pojmowaną kwestią. Żadna inna kwestia na świecie nie była przedmiotem tak dużej liczby głosowań w tak dużej liczbie państw - łącznie w 25 państwach (22 - dzisiejszych państwach członkowskich UE oraz 3 państwach, które nie są w strukturach unijnych).

Biorąc pod uwagę poziom frekwencji wyborczej zauważyć można, iż głosowania powszechne w państwach UE stanowią ważny instrument z perspektywy wyborców, którzy w zdecydowanej większości referendów reprezentują większość uprawnionych do głosowania. Średnia frekwencja w głosowaniach jest na poziomie $64,25 \%$, co świadczy o dużym zaangażowaniu wyborców w europejskie procesy decyzyjne.

Dodatkowo, stwierdzić można, iż proces integracji europejskiej, przyczynił się do wykształcenia nowego typu głosowania - referendum akcesyjnego, którego przeprowadzenie towarzyszy niemal każdej fali rozszerzeniowej.

Nie budzi zatem żadnych wątpliwości fakt, iż jednym z najważniejszych efektów referendów związanych ze sprawami integracji europejskiej jest możliwość wyrażania woli przez poszczególne narody, nie tylko w sprawach o znaczeniu państwowym, ale jednocześnie w kwestii o charakterze ponadnarodowym - europejskim. W referendach 
unijnych przedmiot głosowania nie jest związany wyłącznie z państwem głosującym, ale i z pozostałymi państwami będącymi członkami Unii. Integracja europejska pociąga pewne następstwa w dziedzinie relacji między ponadnarodowością a suwerennością państwową i narodową. Widoczne jest to m.in. w procedurach referendalnych. Skutki referendów bowiem - pomimo że głosowania są przeprowadzane w poszczególnych państwach - mają one wpływ na całą UE i odczuwane są przez wszystkie państwa członkowskie. Elektoraty na szczeblu państwowym podejmują więc decyzje o charakterze ponadnarodowym. Ta właściwość wydaje się być głównym walorem referendów w sprawach związanych z integracją europejską ${ }^{1}$.

\section{Europejska inicjatywa obywatelska jako forma unijnej demokracji bezpośredniej}

W dyskusji nad demokracją bezpośrednią w Unii Europejskiej pojawiało się wiele wątków związanych z ustanowieniem - wspólnych ,unijnych” instrumentów podejmowania decyzji przez obywateli UE (Dehousse, Verhoeven, 2013, s. 3). Szerokie poparcie uzyskał pomysł ustanowienia instytucji ogólnoeuropejskiego referendum, jednak ze względu na trudności, które mogłyby się pojawić przy implementacji tego narzędzia, postanowiono odejść od tego pomysłu.

Mimo iż pomysły ustanowienia instytucji europejskiej inicjatywy powszechnej pojawiły sięjuż w latach 80-tych i 90-tych, to najbardziej podatnym gruntem na propozycję wdrożenia inicjatywy europejskiej okazały się prace nad przygotowaniem Traktatu ustanawiajacego Konstytucję dla Europy. Pomysł ten był intensywnie forsowany przez przedstawicieli różnorodnych organizacji pozarządowych oraz think-thanków promujących demokrację bezpośrednią (np. IRI-Europe), co poskutkowało umieszczeniem zapisów o europejskiej inicjatywie europejskiej w tekście Konstytucji dla Europy praktycznie w ostatniej chwili prac Konwentu Europejskiego - przed podpisaniem roboczej wersji Traktatu (w dniu 12 czerwca 2003 r.). Po wstrzymaniu procesu ratyfikowania Konstytucji dla Europy, przepisy ustanawiające europejską inicjatywę obywatelską włączono do treści Traktatu z Lizbony (Chalmers, 2011, s. 2).

Przepisy dotyczące europejskiej inicjatywy obywatelskiej zostały zdefiniowane w art. 11 ust. 4 Traktatu, który brzmi: ,Obywatele Unii w liczbie nie mniejszej niż milion, mający obywatelstwo znacznej liczby Państw Członkowskich, mogą podjąć inicjatywę zwrócenia się do Komisji Europejskiej o przedłożenie, w ramach jej uprawnień, odpowiedniego wniosku w sprawach, w odniesieniu do których, zdaniem obywateli, stosowanie Traktatów wymaga aktu prawnego Unii”.

Przypomnieć należy, iż europejska inicjatywa obywatelska może dotyczyć każdej z dziedzin, w których Komisja Europejska ma uprawnienia do przedkładania wniosków legislacyjnych (Gracía, 2013, s. 1). Aby nadać bieg inicjatywie obywatelskiej,

1 Przykładem w tym zakresie mogą być: francuskie referendum z 1972 r. (które praktycznie „otworzyło" proces integracji na pozostałe państwa europejskie), irlandzkie referendum w sprawie Traktatu z Nicei (blokujące poszerzanie UE o państwa z byłego bloku wschodniego), czy francuskie referendum (odrzucające „Konstytucję dla Europy” i wprowadzające UE - w tzw. kryzys referendalny). 
musi ona zostać poparta przez co najmniej milion obywateli UE pochodzacych z przynajmniej 7 spośród państw członkowskich UE. W przypadku każdego z tych 7 państw wymagane jest osiagnięcie minimalnej liczby deklaracji poparcia ${ }^{2}$. Zbieranie podpisów pod wnioskiem inicjatywy, nie wymaga zapewnienia, by na liście znalazły się podpisy obywateli każdego państwa członkowskiego (Europejska inicjatywa obywatelska). Deklaracje poparcia należy jednak zgromadzić (Rozporządzenie wykonawcze Komisji...) tak, by zebrać minimalną liczbę deklaracji z co najmniej - jak już wspomniano - siedmiu państw członkowskich (Musiał-Karg, 2012a, s. 217).

Przepisy proceduralne dotyczące europejskiej inicjatywy obywatelskiej określono w rozporządzeniu UE przyjętym przez Parlament Europejski i Radę w lutym 2011 r. (Rozporządzenie Parlamentu Europejskiego i rady (UE)). Dodać należy, że wszystkie przygotowywane do złożenia inicjatywy rejestruje się w jednym portalu, którym zarządza Komisja Europejska: http://ec.europa.eu/citizens-initiative.

W ciągu trzech miesięcy od przedłożenia inicjatywy, pod którą zebrano wymaganą liczbę podpisów, Komisja Europejska za pośrednictwem swoich przedstawicieli ma za zadanie spotkać się z organizatorami inicjatywy, by ci mogli wyjaśnić szczegółowo kwestie, jakich dotyczy inicjatywa. Oprócz tego, inicjatorzy mają możliwość zaprezentowania swojej inicjatywy na forum Parlamentu Europejskiego podczas wysłuchania publicznego. Po precyzyjnym przeanalizowaniu inicjatywy, Komisja Europejska musi przyjąć oficjalne stanowisko, wyjaśnić i uzasadnić kierunek swoich działań. Komunikat Komisji musi mieć „formę oficjalnego dokumentu przyjętego przez kolegium komisarzy i opublikowanego we wszystkich językach urzędowych UE. W niektórych przypadkach Komisja może wydać jedynie wstępną opinię, a decyzję ostateczną podjąć w oparciu o kolejne analizy danej sprawy. Jeżeli w odpowiedzi na inicjatywę obywatelską Komisja zdecyduje się przedstawić wniosek w sprawie aktu prawnego, rozpoczyna się proces legislacyjny - Komisja przedkłada swój wniosek legislacyjny ustawodawcy (Parlamentowi Europejskiemu i Radzie, a w niektórych przypadkach tylko Radzie). Dopiero po zatwierdzeniu przez ustawodawcę projekt staje się aktem prawnym" (Europejska inicjatywa obywatelska. Przewodnik, 2011, s. 26).

Do tej pory status zakończonych inicjatyw przypisanych ma 9, z których dwie zostały już rozpatrzone przez Komisję Europejską (Tabela 1).

Na stronach internetowych Komisji Europejskiej (w dziale poświęconym europejskiej inicjatywie obywatelskiej) widnieją ponadto informacje o trwających inicjatywach (obecnie trwają 3) (Trwajace inicjatywy) oraz o kilkunastu nieaktualnych (wycofanych przez inicjatorów lub tych, które nie uzyskały odpowiedniego poparcia) (Nieaktualne inicjatywy). Analiza dostępnych głównie na stronach internetowych Komisji Europejskiej danych na temat składanych inicjatyw europejskich pozwala przypuszczać, iż nie będzie to efektywne narzędzie decydowania politycznego wykorzystywane przez obywateli UE. Supozycje te wynikają przede wszystkich z analizy przedmiotów złożonych inicjatyw, które nie należą raczej do kwestii o priorytetowej roli. Wydaje się, że traktaty unijne o kluczowym dla UE znaczeniu czy reformy w ramach Unii nie będą przedmiotem

2 Szczegółowe informacje nt. minimalnej liczby sygnatariuszy, przypadającej na państwo członkowskie: Europejska inicjatywa obywatelska, Komisja Europejska, http://ec.europa.eu/citizens-initiative/public/signatories, 15.08.2014. 
europejskich inicjatyw obywatelskich, co bez wątpienia „obniża” niejako rangę tego instrumentu.

Podsumowując rozważania na temat demokracji bezpośredniej na poziomie unijnym, zaznaczyć należy, iż europejska inicjatywa obywatelska jest jedynym w skali świata transnarodowym instrumentem o takim charakterze. Wprowadzony Traktatem z Lizbony instrument traktowany na poziomie UE jest jako narzędzie umożliwiające obywatelom bezpośredni wpływ na europejskie procesy polityczne (Europejska Inicjatywa Obywatelska, MSZ, 2011, s. 6).

Tabela 1

Zakończone inicjatywy (stan na 25.08.2014 r.)

\begin{tabular}{|c|c|c|c|c|}
\hline & Tytul & $\begin{array}{l}\text { Data } \\
\text { rejestracji }\end{array}$ & $\begin{array}{c}\text { Data } \\
\text { zakończenia }\end{array}$ & \\
\hline \multirow{7}{*}{$\begin{array}{l}\text { Zakończono } \\
\text { zbieranie } \\
\text { podpisów* }\end{array}$} & Europejska inicjatywa na rzecz pluralizmu mediów & 19.08 .2013 & 19.08 .2014 & \\
\hline & ACT 4 Growth & 10.06 .2013 & 10.06 .2014 & \\
\hline & Let me vote & 28.01 .2013 & 28.01 .2014 & \\
\hline & $30 \mathrm{~km} /$ godz - ulice przyjazne życiu! & 13.11 .2012 & 13.11 .2013 & \\
\hline & $\begin{array}{l}\text { Central public online collection platform for the Eu- } \\
\text { ropean Citizen Initiative }\end{array}$ & 27.08 .2012 & $1.11 .2013^{* *}$ & \\
\hline & Zawieszenie Pakietu Klimatyczno-Energetycznego UE & 8.08 .2012 & $1.11 .2013^{* *}$ & \\
\hline & Stop Wiwisekcji & 22.06 .2012 & $1.11 .2013 * *$ & \\
\hline $\begin{array}{l}\text { Przedłożone } \\
\text { Komisji } * * *\end{array}$ & Brak & & & \\
\hline \multirow{2}{*}{$\begin{array}{l}\text { Rozpatrzone } \\
\text { przez Komi- } \\
\text { sję**** }\end{array}$} & Jeden $\mathrm{z}$ nas & 11.05 .2012 & 1.11 .2013 & $\begin{array}{c}\text { Rozpatrzono } \\
28.05 .2014\end{array}$ \\
\hline & $\begin{array}{l}\text { Dostęp do wody i kanalizacji jest prawem człowie- } \\
\text { ka! Woda jest dobrem publicznym, nie towarem! }\end{array}$ & 10.05 .2012 & 20.12 .2013 & 19.03 .2014 \\
\hline
\end{tabular}

* Lista inicjatyw, w przypadku których gromadzenie deklaracji zostało zakończone. Inicjatywy te nie zostały jeszcze przedłożone Komisji. Komisja nie dysponuje informacją, czy organizatorom udało się zebrać wymaganą liczbę deklaracji poparcia czy nie.

** Nowy termin wyznaczony ze względu na problemy, o których informowali organizatorzy na początkowym etapie inicjatywy obywatelskiej. Więcej informacji: http://ec.europa.eu/commission_2010-2014/sefcovic/headlines/press-releases/2012/07/2012_07_18_eci_en.htm, 15.08.2014.

*** Lista inicjatyw, w przypadku których zebrano wymaganą liczbę deklaracji poparcia i które oczekują na odpowiedź Komisji.

**** Lista inicjatyw, w przypadku których Komisja przedstawiła już swoje wnioski.

Źródło: Zakończone inicjatywy, Komisja Europejska, http://ec.europa.eu/citizens-initiative/public/initiatives/finalised/answered, 25.08.2014.

W dyskusji nad rolą europejskiej inicjatywy obywatelskiej zaznacza się ponadto, iż dzięki inicjatywie możliwe będzie zwiększenie poziomu uczestnictwa w życiu politycznym oraz budowanie świadomego społeczeństwa obywatelskiego, zarówno na poziomie unijnym, jak i krajowym. Opinie te wydają się być przynajmniej na wyrost, bowiem europejska inicjatywa - wzorowana na bezpośredniej inicjatywie powszechnej w Szwajcarii - działa zupełnie inaczej niż jej helwecki wzór. W Szwajcarii bowiem po zebraniu odpowiedniej liczby podpisów, przedmiot inicjatywy automatycznie trafia pod głosowanie powszechne, w którym to obywatele (a nie instytucje polityczne) decydują o dalszych losach przedmiotu głosowania (Musiał-Karg, 2012b, s. 123-124). 
Reasumując, zaznaczyć zatem należy, iż mimo krytyki, europejska inicjatywa może być pierwszym niewielkim (ale ważnym) krokiem w kierunku tworzenia wspólnotowych ponadnarodowych instytucji demokratycznych, dzięki którym obywatele będą mieli możliwość nie decydować, ale inicjować zmiany dotyczące raczej mało popularnych problemów dotykających społeczeństwo europejskie (Aloisio, Grimaldi, Morelli, Padoa-Schioppa, 2011, s. 67).

\section{Podsumowanie}

Na poziomie państwowym demokracja bezpośrednia stanowi istotną formę sprawowania władzy uzupełniającą demokrację przedstawicielską. Większość państw członkowskich ma doświadczenia związane $\mathrm{z}$ bezpośrednim podejmowaniem decyzji przez obywateli, a integracja europejska jest jednym $\mathrm{z}$ ważnych zagadnień przedkładanych uprawnionym do rozstrzygnięcia. Przede wszystkim referendum ogólnonarodowe zasługuje w tym miejscu na uwage - w przeciagu 42 lat przeprowadzono bowiem 54 głosowania w kwestiach europejskich. Żadna sprawa na świecie nie była przedmiotem tak wielu głosowań powszechnych w tak dużej liczbie państw.

Jeśli chodzi o Unię Europejską, to zaznaczyć należy, iż ta ponadnarodowa struktura, w ciagu ostatniej dekady szukała sposobów zbliżenia się, zmniejszenia dystansu, do swoich obywateli. Wprowadzając europejską inicjatywę obywatelska Unia poprawiła funkcjonowanie swoich instytucji przedstawicielskich poprzez wzmocnienie roli Parlamentu Europejskiego i jego kontroli nad Komisją i nad procesem legislacyjnym (Gracía, 2013, s. 23).

Zaznaczyć przy tym należy, iż europejską inicjatywę obywatelską (oprócz narodowych referendów) zaliczyć należy do instytucji demokracji bezpośredniej, które mają pomagać obywatelom wpływać na decyzje w sprawach związanych z UE, na kształt polityk unijnych. Warto zwrócić uwagę na fakt, iż inicjatywa europejska - w przeciwieństwie do tzw. referendów narodowych w sprawach integracji europejskiej-jest usankcjonowaną w prawnie instytucją o charakterze europejskim, której przedmiotem mogą być kwestie wyłącznie europejskie (gdyby to były kwestie narodowe - trudno byłoby zebrać milion podpisów z 7 różnych państw członkowskich).

Komisja Europejska stwierdziła optymistycznie; że europejska inicjatywa obywatelska - poprzez „integrowanie” obywateli z różnych państw członkowskich w jednej konkretnej sprawie - stanowi swoistą możliwość przybliżenia Unii obywatelom i wspierania większej transnarodowej debaty nad kształtem polityk UE. Założenie to sugeruje, iż poprzez samo złożenie podpisu pod wnioskiem inicjatywy niejako automatycznie zwiększy się poziom poinformowania obywateli o polityce UE, czy o procesie podejmowania decyzji unijnych. Odnotować jednak należy, iż prawdopodobnie instrument europejskiej inicjatywy nie będzie się przekładał na szybki, zauważalny wzrost wiedzy obywateli UE. To narzędzie bowiem - jak zaznaczają Paweł Głogowski i Andreas Maurer - wykorzystane jest przez obywateli już bardzo dobrze lub dobrze poinformowanych, którzy świadomie próbują wpłynąć na kształt ważnych dla nich spraw europejskich (2013, s. 24). 
Zwrócić w tym miejscu należy uwagę, iż nadal większość obywateli UE nie ma praktycznie żadnej wiedzy na temat europejskiej inicjatywy obywatelskiej. Badania Eurobarometru z 2012 r. wskazują, iż jedynie 3\% obywateli Unii potwierdziło, że z dużym prawdopodobieństwem wykorzystają europejską inicjatywę obywatelską, natomiast dwie trzecie respondentów zadeklarowało, że nie będzie stosować tego instrumentu (European Citizenship, Standard Eurobarometer 77, 2012).

Kryzys gospodarczy jeszcze bardziej niż wcześniej uwypuklił w Unii potrzebę zwiększania poziomu legitymizacji UE, a tym samym niwelowania deficytu demokratycznego. W tym kontekście europejska inicjatywa obywatelska wydaje się być istotnym narzędziem demokracji unijnej. Fakt ten wynika zapewne $\mathrm{z}$ tego, iż bez wątpienia inicjatywa jest narzędziem bardziej bezpośrednim i ponadnarodowym niż jakikolwiek inny instrument demokratyczny na poziomie UE (Kaufmann, 2012, s. 11).

Wydaje się jednak, iż mimo uregulowania europejskiej inicjatywy obywatelskiej w prawie UE, narzędzie to wykorzystywane będzie raczej w sprawach o mniejszym znaczeniu dla funkcjonowania Unii. W zagadnieniach kluczowych - jeśli społeczność europejska będzie angażowana w proces decyzyjny - narzędziem, za pośrednictwem którego będą podejmowane decyzje będzie referendum narodowe. Głosowanie to będzie jedną z form decydowania o pogłębianiu i poszerzeniu procesu integracji w Europie. Reasumując, zaznaczyć więc należy, iż w europejskich sprawach najwyższej wagi instrumentem demokracji bezpośredniej, który wykorzystywany będzie w procesie decyzyjnym będzie nadal referendum narodowe. Europejska inicjatywa obywatelska będzie natomiast służyć inicjowaniu spraw mniej istotnych - nienależących do najważniejszych zagadnień polityki europejskiej.

\section{Bibliografia}

Aloisio S., Grimaldi G., Morelli U., Padoa-Schioppa A. (2011), The European Citizens' Initiative: Challenges and Perspectives, w: Democracy in the EU after the Lisbon Treaty, red. R. Matarazzo, Edizioni Nuova Cultura, Rome.

Berg C. (2008), The European Citizen's Initiative process, ECI Campaign Working Paper, http://wiki.citizens-of-europe.eu/images/a/a7/100209_paper.pdf, 10.10.2014.

Berg C. (2009), EU Commission's proposal for ECI needs improvement!, ECI Campaign Working Paper, http://wiki.citizens-of-europe.eu/images/8/8a/091128_eci-news.pdf, 10.10.2014.

Chalmers A. W. (2011), Direct Democracy for the EU. A Place for Interest Grupos in the European Citizens'Initiative, Working Paper FG 1, 05, SWP Berlin.

Dehousse F., Verhoeven D. (2013), The European Citizens'Initiatove: Next Bog Thing or New False Good Idea?, Egmont Paper 59, Royal Institute for International Relations, Academia Press.

European Citizenship, Standard Eurobarometer 77, Spring 2012, http://ec.europa.eu/public_opinion/archives/eb/eb77/eb77_citizen_en.pdf, 11.12.2014.

Europejska inicjatywa obywatelska, Komisja Europejska, http://ec.europa.eu/citizens-initiative/public/basic-facts, 13.03.2014.

Europejska Inicjatywa Obywatelska, MSZ, Warszawa 2011, http://www.cie.gov.pl/HLP/files.nsf/ 0/FF5CC0636B37D7DEC1257990004D2C98/\$file/Europejska_inicjatywa_obywatelska.pdf, 12.06.2014. 
Europejska inicjatywa obywatelska. Przewodnik, Komisja Europejska, Luksemburg 2011.

Grecja: będzie referendum w sprawie pakietu pomocowego, 31.10.2011, Wprost.pl, http://www.wprost.pl/ $\operatorname{ar} / 268087 /$ Grecja-bedzie-referendum-w-sprawie-pakietu-pomocowego/, 11.10.2012.

García L. B. (2013), The Significance of the European Citizens'Initiative for Pan-European Participatory Democracy, International Institute for Democracy and Electoral Assistance (International IDEA), Stockholm.

Grecja: referendum w sprawie pakietu?, 3.11.2011, http://www.uniaeuropejska.org/grecja-referendum-w-sprawie-pakietu-ratunkowego, 11.03.2014.

Hassing J., The Citizens' Initiative: A Participatory Cure for Europe? An Early Assessment of the Citizens' Initiative', Think Global - Act European (TGAE) Report. Notre Europe, Paris.

Kaufmann B. (2011), Into the Practice - Steps and Structures to Make the European Citizens'Initiative a democratic success story, w: red. J. W. Pichler, B. Kaufmann, The Next Big Thing. Making Europe ready for the Citizens' Initiative, Intersentia, Wiedeń.

Kużelewska E. (2001), Proces ratyfikacji Traktatu ustanawiajacego Konstytucję dla Europy i jego nastęstwa, Warszawa.

Kużelewska E. (2006), Referendum w procesie integracji europejskiej, Warszawa.

Mayoral J. (2011), Democratic improvements in the European Union under the Lisbon Treaty Institutional changes regarding democratic government in the EU, European Union Democracy Observatory (EUDO) Robert Schuman Centre for Advanced Studies, European University Institute, http://www.eui.eu/Projects/EUDO-Institutions/Documents/EUDOreport922011.pdf, 10.10.2014.

Musiał-Karg M. (2008), Referenda w państwach europejskich. Teoria, praktyka, perspektywy, Wydawnictwo Adam Marszałek, Toruń.

Musiał-Karg M. (2012a), Instytucje demokracji bezpośredniej w procesie integracji europejskiej-od referendum ogólnonarodowego do europejskiej inicjatywy obywatelskiej, „Rocznik Integracji Europejskiej”, nr 6.

Musiał-Karg M. (2012b), Elektroniczne referendum w Szwajcarii. Wybrane Kierunki zmian helweckiej demokracji bezpośredniej, WNPiD UAM, Poznań.

Nieaktualne inicjatywy, Komisja Europejska, http://ec.europa.eu/citizens-initiative/public/initiatives/obsolete/conditions_not_fulfilled, 25.08.2014.

Premier Papandreu odchodzi. To cena za propozycję referendum. „Grecja nadużyła zaufania Unii”, 7.11.2011, http://wpolityce.pl/polityka/121539-premier-papandreu-odchodzi-to-cena-za-propozycje-referendum-grecja-naduzyla-zaufania-unii, 11.03.2014.

Rozporządzenie Parlamentu Europejskiego i rady (UE) nr 211/2011 z dnia 16 lutego 2011 r. w sprawie inicjatywy obywatelskiej, „Dziennik Urzędowy Unii Europejskiej” L 65/1, http://eur-lex.europa.eu/LexUriServ/LexUriServ.do?uri=OJ:L:2011:065:0001:0022:PL:PDF, 13.03.2014.

Rozporządzenie wykonawcze Komisji (UE) nr 1179/2011 z dnia 17 listopada 2011 r. ustanawiajace specyfikacje techniczne $w$ odniesieniu do systemów zbierania deklaracji on-line na mocy rozporzqdzenia Parlamentu Europejskiego i Rady (UE) nr 211/2011 w sprawie inicjatywy obywatelskiej, http://eur-lex.europa.eu/LexUriServ/LexUriServ.do?uri=OJ:L:2011:301: 0003:0009:PL:PDF, 13.03.2014.

Sauron J-L. (201 1), The European Citizens'Initiative: not such a good idea?, Robert Schuman Foundation Policy Paper, http://www.robert-schuman.eu/doc/questions_europe/qe-192-en.pdf, 10.11.2014.

Trwajace inicjatywy, Komisja Europejska, http://ec.europa.eu/citizens-initiative/public/initiatives/ ongoing, 25.08.2014. 


\section{Streszczenie}

Stawiając pytanie o naturę rozwiązań instytucjonalnych przyjętych w Unii Europejskiej, oczywistą odpowiedzią jest ta, iż fundamentem funkcjonowania systemu politycznego samej Unii - podobnie zresztą jak wszystkich jej państw członkowskich - jest demokracja przedstawicielska. Pośrednie instrumenty rządzenia często uzupełniane są formami demokracji bezpośredniej, za pomocą których uprawnieni do głosowania mają możliwość bezpośredniego wpływu na kształt agendy politycznej. Przedmiotem niniejszych rozważań jest zagadnienie roli bezpośrednich mechanizmów decydowania politycznego w procesie integracji europejskiej, ze szczególnym uwzględnieniem funkcjonującej od 2012 r. europejskiej inicjatywy obywatelskiej. Celem niniejszego tekstu jest udzielenie odpowiedzi na pytanie o rolę i perspektywy rozwoju europejskiej inicjatywy obywatelskiej jako instrumentu wpływu obywateli na decyzje związane z procesami integracji w UE.

Słowa kluczowe: europejska inicjatywa ludowa, demokracja bezpośrednia, UE

\section{The European Citizens' Initiative - remarks on the role of citizens in the process of European integration}

\section{Summary}

When thinking about the character of the institutional solutions adopted in the European Union, it is clear that the political system of both the EU and all its member states is founded on representative democracy. Direct forms of governance are frequently complemented by instruments of direct democracy, which allow voters to exercise a direct influence on the political agenda. The subject of the considerations in this paper concerns the role of direct mechanisms of political decision-making in the process of European integration, with particular emphasis given to the European Citizens' Initiative, operating since 2012. This paper aims to answer the question of the role and prospects for future development of the European Citizens' Initiative as a tool of the influence of citizens on decisions concerning EU integration processes.

Key words: European Citizens' Initiative, direct democracy, EU 
